\title{
Self-Efficacy Career and the Career Maturity of Teenagers at the Exploration Stage
}

\author{
Mohd Jahidi bin Rosdi ${ }^{1}$, Jasmi bin Abu Talib², Norwaliza binti Abd. Wahab ${ }^{3}$ \\ ${ }^{1}$ Jempol Community College, 72100 Mahsan, Bahau, Negeri Sembilan, Malaysia \\ ${ }^{2}$ Terengganu University of Malaysia, 21030 Kuala Terengganu, Terengganu, Malaysia, \\ ${ }^{3}$ Sultan Idris Education University, 35900, Tanjung Malim Perak, Malaysia
}

\begin{abstract}
The purpose of this research is to check out the effect of Career Exploration Module on the self-efficacy career and the career maturity among the students in the college community. This research is in the form of quasi-experiments pre and posttest in a control group that are not equivalent. (Non-equivalent pretest and posttest control group design). As much as 122 students in semester 4 in both of the community college in Malacca are being taken as a sample for this research. The data are collected by using two set of instruments. i)Career Maturity Inventory-Revised-CM-R to measure the attitude and efficiency of a student in planning a career. ii) Career Decision Making Self Efficacy Scale-Short Form CDMSE-SF to measure the level of self-efficacy career in students. The reliability of this research instrument has been analyses by using a method Alpha Cronbach and the value for both of this instrument are exceeding .70. The data are being analyses in a descriptive and inferential way. The analyzing descriptive by using mean is the frequency and percentage to see the different between two groups. On the other hand, the inferential analysis is using MANOVA method in order to see the different between groups after the experiment have been done. The findings of the research show that there is min difference that is significant between the controlled group and the experiment groups for the variables self-efficacy career and career maturity after the experiment. Results of this research proved that, self-efficacy career and career maturity can be upgraded if the students follow a systematic career program. The use of Career Exploration Module is proven to be effective for students of college community to build and increasing their career skills.
\end{abstract}

Keywords: self-efficacy career, career maturity, community college, Career Exploration Module

\section{Introduction}

The Self-efficacy concept was first introduced by Albert Bandura (1977) through its Social cognitive theory. This concept was later tried to associate with psychological career by Betz \& Hackket (1981) through the Social Cognitive Theory Career Self-Efficacy. Betz \& Hackket (1981) defines the career self-efficacy is the belief and confidence in an individual comprising the ability to work, the selection of courses to study at the colleges and efforts and perseverance in carrying out the choices made. Mitchell et al. (2004), defines that self-efficacy as the belief that people's ability to do things. He added that the abilities are also related to the ability to run the job properly. Meanwhile Lent , Brown and Hackett (1996 ) ; Gysberg et al . (2003) tied the efficacy as the experience taken from the past experience that can be used to achieving self-efficacy, which can lead to form a new career, which eventually led to the formation of a new achievement goal that are more favorable and excel in the chosen career.

On the other hand, the career maturity is a concept put forward by Donald E. Super (1957) in the career development theory. Career maturity is defined as an individual ${ }^{\text {ee }} \mathrm{s}$ readiness to confront all forms of assignment needs to be done at each stage of development. This theory suggests the behavior of a vocation that should happen at each stages of the career development. According to Super (1957), the youth need to master and complete the developmental task given at the exploration stage. If the career behavior can be expected or perceived, the more mature a person in the terms of self-making career development. The individuals who have higher career maturity will be able to think, act and make right decisions that related to his career. A completion of task at each stage of development will enable the young generations to achieve optimum ripeness in the future (Crites, 1978). Meanwhile, oetzee \& Roythorne Jacobs (2007 ), Schreuder and Coetzee (2006 ) argues that the career maturity refers to an abilities of a person to be able to make a career decisions that reflect decisiveness, self-reliance , independence , and a willingness to compromise between personal needs and requirements of the person state's career. Preliminary studies have been carried out on community college students have given preliminary information related to the issue that available among them. The studies of Mobility Services Personnel Community College Students nationwide have found, among the aspects that become a major problem for students is: i) Do not know how to do the future plans, ii) Not sure about the work that will be taken, Need a help in finding a job, does not know how to find a job low self-esteem and fear of unemployment (Mizan 2005). This posed a problem that can be attributed to what is stated by Super (1957) and Betz \& Hackett (2002), the career maturity and career self-efficacy. According to them, these elements need to be emphasized in the process of deciding on a career. Feedback from employers, where students undergo industrial training also said that students expressed a lack of understanding and lack of confidence to perform a given task. Furthermore, elements such as communication skills, personality, and lack of discipline, the ability to execute commands and less creativity and enthusiasm are also a major problem in the training place. (A report from the Industrial Training Unit Community College, Masjid Tanah, 2009). The employer's 


\section{International Journal of Science and Research (IJSR) \\ ISSN (Online): 2319-7064}

Index Copernicus Value (2013): 6.14 | Impact Factor (2015): 6.391

response may be associated with students lack in career selfefficacy. Low self-efficacy career appeared to cause difficulties to see other forms of career that they want to choose later (Betz, et al., 1996). In addition, the feedback obtained through Tracer Study Community College from 2008 to 2010 shows that interpersonal and intrapersonal skills are among the additional skills that are indispensable besides to support programs such as English-language skills, ICT skills and entrepreneurial skills. The preliminary information that have been obtained are giving implication to the need to implement a comprehensive career program that can trace the career self-efficacy and career maturity of community college students. According to the assumption of Career Development Theory Super (1957) students at the age of 18-24 years are at the exploratory stage of career development and the main activities that should be done by the students is to explore as many career information. In addition they also should get exposed to a career program that can provide information to them. The more the students are exposed to career information and the more increase in their maturity level. Teens who can accomplish development task at the exploration stage will typically achieve a more optimal career maturity (Super 1957).So to help raise the career self-efficacy and career maturity among community college students, a one career intervention for modular have been introduced. Method interventions career modularly has been proven by previous researchers (Devarajoo 2002; Tan, 2004; Abd Hanid 2007; Andreas 2008; Syed 2007; Miles, 2008; Thuria Moore, 2003; Bleir, 2006; Poh et al., 2010; Hassan 2009; Medina, 2010; Jacob 2011). The study also proves involvement in a structured career program provides opportunities for students with low achievement to build their own potential. (Hirschi \& Lage 2008; Mediante 2011). In another study also proves, development does not just happen in terms of career planning, career decision-making and science careers but also involves others in their selfdevelopment (Castellano, Stone, Stringfield, Farley, \& Wayman 2004; Hughes \& Karp, 2004 ). Up to now there has been no follow-up study, which was conducted in response to the issues that were among community college students. Although studies related interventions careers have run in this country, but it is more concentrated among high school students and look to other aspects rather than the selfefficacy of career and career maturity (Amla 2002; Devarajoo 2002; Sidek 2002; Tan, 2004; Abd Hanid 2007 ; Syed 2010; Poh et al., 2010; Sani, 2011). There has been no study that have been run in the college or university level in this country, while this study have been run many times at the college from other country and proven that the intervention programs career has had a positive effect on self-efficacy of career and career maturity of students (Brown 2000; Richard, 2001; Gail \& Kelly 2004; Scot \& Ciani's, 2008; Sara June 2006; Daria, 2006; Medina 2010; Hamilton, 2011). There are gaps, especially studies that look at the aspects of career self-efficacy and career maturity for career intervention methods using modules among community college students. To fill the voids that exist, this study has been carried out. This study tested the Career Exploration Module that has been given added value by entering the appropriate skills to community college students such as interview skills, resume preparation and how to write job application letters. The main objective of this study is to look at the differences career self-efficacy and career maturity of students at two community colleges in the state of Malacca.

\section{Methodology}

This study used a quasi-experimental design of pre-test and post-test non-equivalent control group (non-equivalent pretest and post-test control group design) (Campbell and Stanley 1963, Salkin 2000, Wiersma, 1991). The experimental group has attended the workshop for career that using the Career Exploration Module for 9 weeks (18 hours), while the controlled group is learning in a class following the usual schedule. A sample of 122 respondents (56 women and 66 men) was selected using purposive sampling. This sample are consisted of students from courses Hotel and Catering Certificate, Certificate in Automotive, Computer Systems and Support Certificate and Certificate of landscape of two community colleges (Masjid Tanah Community College and Bukit Beruang Community College) in Malacca. Two sets instrument ere used for data collection, i) Career Maturity Inventory Questionnaire Revised (1995) - Career Maturity Inventory - Revised (CM-R) by John O Crites and Savickas - translated by Sani (2011, ii) Self-Efficacy Scale career Summary (1996) - Career Decision Making Self efficacy Scale-Short Form (CDMSE-SF) by Betz et al. (1996) which was translated by Sani (2011). The reliability assessment path of the instrument was conducted and involved 30 students from semester four at Community College Jasin. Cronbach's value for both instrument are 0.96 and 0.94 for the CMR and CDMSE-SF.

\section{Research Result}

\subsection{Mean Career self-efficacy scores of the experimental group and the control group}

Mean score of self-efficacy career based on the group that showed a mean difference between the experimental group and the control group, pre-test (experiment, mean $=3.97$, sd $=0.38$, control, mean $=3.99$, sd $=0.38$ ), the post-test (experiment, $\min =4: 01, \mathrm{sp}=0.37$, control, mean $=3.56$, sd $=0.35)$. $($ Table 1$)$

Table 1: Shows the mean differences career self-efficacy tests pre and post based on groups

\begin{tabular}{|c|c|c|c|c|c|}
\hline Group & $\mathrm{N}$ & $\begin{array}{c}\text { Mean of } \\
\text { pre self }- \\
\text { efficacy }\end{array}$ & $\begin{array}{c}\text { Standard } \\
\text { deviation }\end{array}$ & $\begin{array}{c}\text { Self- } \\
\text { Efficacy } \\
\text { Mean post }\end{array}$ & $\begin{array}{c}\text { Standard } \\
\text { deviation }\end{array}$ \\
\hline Experiment & 61 & 2.64 & .30777 & 3.74 & .53194 \\
\hline Controlling & 61 & 2.83 & .34709 & 2.53 & .39463 \\
\hline
\end{tabular}

To ensure that career self-efficacy mean difference is significant at the level of $\mathrm{p}<0.017$, MANOVA analysis was conducted. The results show the difference was significant, $\mathrm{F}$ $=176,020, \mathrm{p}=0.000, \mathrm{p}<0.017$. This means Career Exploration Module effectively enhance self-efficacy career experimental groups. (Table 2) 


\section{International Journal of Science and Research (IJSR) \\ ISSN (Online): 2319-7064}

Index Copernicus Value (2013): 6.14 | Impact Factor (2015): 6.391

Table 2: Shows the mean difference between groups of career self-efficacy

\begin{tabular}{|c|c|c|c|c|c|c|c|}
\hline \multirow{2}{*}{ Dependent Variable } & \multirow{2}{*}{ ( I ) Strategy } & \multirow{2}{*}{ ( J ) Strategy } & \multirow{2}{*}{$\begin{array}{c}\text { Mean } \\
\text { Differences I - J }\end{array}$} & \multirow{2}{*}{$\begin{array}{l}\text { Standard } \\
\text { Deviation }\end{array}$} & \multirow{2}{*}{ Significant. } & \multicolumn{2}{|c|}{ Confident Level 95\% } \\
\hline & & & & & & Lower Limit & Upper Limit \\
\hline \multirow[b]{2}{*}{ Self-Efficacy Career } & Module & Non module & 1.27 & 0.96 & 0 & 1.08 & 1.46 \\
\hline & Non Module & Module & -1.27 & 0.4 & 0 & -1.46 & -1.08 \\
\hline
\end{tabular}

\subsection{Mean for career maturity scores of the experimental group and the control group.}

Mean score of career maturity based group showed a mean difference between the experimental group and the control group, pre-test (experiment, mean $=3.00$, sd $=.19596$, control, mean $=3.16$, sd $=.22320$ ), the post-test (experiment, $\min =3: 45, \mathrm{sp}=.19782$, control, mean $=3.27$, sd $=0.18668)$. (Table 3$)$

Table 3: Shows the mean difference in career maturity based on pre and post - test group

\begin{tabular}{|c|c|c|c|c|c|}
\hline Group & $\mathrm{N}$ & $\begin{array}{c}\text { Mean pre } \\
\text { Career } \\
\text { Maturiy }\end{array}$ & $\begin{array}{c}\text { Standard } \\
\text { Deviation }\end{array}$ & $\begin{array}{c}\text { Mean } \\
\text { post } \\
\text { career } \\
\text { maturity }\end{array}$ & $\begin{array}{c}\text { Standard } \\
\text { Deviation }\end{array}$ \\
\hline Experiment & 61 & 3.00 & .19596 & 3.45 & .19782 \\
\hline Controlling & 61 & 3.16 & .22320 & 3.27 & .18668 \\
\hline
\end{tabular}

To ensure that the mean differences of the career maturity level is significant at $\mathrm{p}<0.017$, MANOVA analysis was conducted. The findings show that the difference is significant, the value of $\mathrm{M}=21604, \mathrm{p}=0.000, \mathrm{p}<0.017$. This means „Exploration Career Modulee is effective in improving the career maturity experimental group. (Table 4)

Table 4: Shows the mean difference between the groups career maturity

\begin{tabular}{|c|c|c|c|c|c|c|c|}
\hline \multirow{2}{*}{ Dependent Variable } & \multirow{2}{*}{ ( I ) Method } & \multirow{2}{*}{ ( $\mathrm{J}$ ) Method } & \multirow{2}{*}{$\begin{array}{c}\text { Mean } \\
\text { Different I - J }\end{array}$} & \multirow{2}{*}{ Error } & \multirow{2}{*}{ Significant. } & \multicolumn{2}{|c|}{ Confident Level 95\% } \\
\hline & & & & & & Lower Limit & Upper Limit \\
\hline \multirow{2}{*}{ Career Maturity } & Module & Non module & 1.86 & 0.04 & 0 & 0.107 & 205 \\
\hline & Non module & Module & -1.86 & 0.04 & 0 & -205 & -107 \\
\hline
\end{tabular}

\section{Summary and Conclusions}

The results prove Career Exploration Module effectively enhance self-efficacy and career maturity among community college students. The increase in career self-efficacy and career maturity of this experimental group are the effects from the activities of Career Exploration Module implemented in the form of workshops that have given a boost and new experiences to students. This is consistent with what was stated by (Lent, Brown \& Hackett, 1996; Gysberg et al. 2003), where the experience of past achievements, can form self-efficacy a new career, which will leads to the formation of a new expected results and ultimately lead to of the new goals achievement that are more instigate and outstanding in the chosen career. From this aspects of career maturity, these findings are consistent with what is stated by Super (1957), the more we exposed the students with career information and the higher their maturity increases. The results of this experiment is also consistent with the findings of previous studies that also founded the involvement of students in career modular program has managed to increase self-efficacy and career maturity of their careers. ( Sullivan \& Mahalik, 2000; Richard, 2001; Scot \& Ciani's, 2008; Medina, 2010; Mediante, 2011; Thuria Moore, 2003; Bleir, 2006; Sani, 2011; Gail \& Kelly, 2004; Poh et al., 2010 ; Devaraajoo, 2002; Tan, 2004; Legum \& Hoare, 2004; Andrew, 2007 ). This means that the career self-efficacy and career maturity can be increased if students are exposed to a career program that is informative especially based on modules. The results of this experiment also bring two theoretical implications. First, assuming Super Career Development Theory (1957), which assumes the exploration information, will increase the maturity of individual careers. Individuals who are at the exploration stage (ages 18-24) must do surveillance towards the career-related information. Exploration on the information can develop an interest, satisfaction and make people more confident and able to make judgments based on the collected career information. This is suitable with the activities that have been passed by the students during the workshop career with Career Exploration Module which is more focused on the exploration information of career. Moreover, this theory assumes that the career maturity of the individual can be improved if the individual's attention and show interest in the career development process. Individuals can increase their interest and the maturity of their careers if exposed to an environment that can stimulate them towards it (Hamilton, 2011; Hirschi \& Lage, 2008; Medina, 2010). Career events throughout the career workshop using this Career Exploration Module can provide experiences that encourage students to improve their ability to plan and make their careers more mature in determining the direction of their careers.

Second, the findings also indicate the level of career selfefficacy can be increased with the elements of encouragement, support, experience and interaction with the environment. This assumption is consistent with Bandura's Social Cognitive Theory (1977), which presupposes selfefficacy can be improved through experience, learning, motivation and encouragement as well as individual interaction with the environment. In this study"s context, it is conducted in an environment of a workshop setting career has given students the opportunity to interact with fellow participants. In addition, assistance, encouragement and incentives provided by the facilitator also contributed to the improvement of students' career self-efficacy. In practical implications, this study proves that the career intervention 


\section{International Journal of Science and Research (IJSR) \\ ISSN (Online): 2319-7064}

Index Copernicus Value (2013): 6.14 | Impact Factor (2015): 6.391

program using the Career Exploration Module contribute to the improvement of career self-efficacy and career maturity of students. Career Exploration Module activities is focusing on aspects of the work environment, exploration of career information and job setup that includes resume preparation, cover letter and job interview preparation. All of these elements must be the focus in the career program in the future. As the conclusion, the results of this study give the implication that the use of the Career Exploration Module. Career Program is proven to increase self-efficacy career and career maturity of community college students. This module can also be used for student at other higher learning institutions.

\section{References}

[1] Abd Hanit bin Halit. (2007). Keberkesanan program Kerjaya keatas perkembangan Kerjaya peringkat penerokaan dalam kalangan pelajar sekolah menengah di Daerah Dungun Terengganu. Tesis. Dr. Fal. Universiti Putra Malaysia, Serdang.

[2] Amla Salleh. (2002). Memindahkan ujian psikologi: Kaedah menterjemah dan mengubahsuai "Self Directed Search" (Holland) ke dalam bahasa melayu. Jurnal Pendidikan16: 23-34.

[3] Andreas Hirschi., Damian .L. (2008). Increasing the Career Choice Readiness of Young Adolescents: An Evaluation Study. Education Vocational Guidance 8:95-110.

[4] Bandura, A. (1977). Social Learning Theory. Englewood Cliffs, NJ: Prentice-Hall, Inc.

[5] Bandura, A. (1997). Self efficacy: the exercise of control. New York: Freeman and Company.

[6] Betz, N. E. \& Hackett, G. (1981). The relationship of career related self-efficacy expectation to perceived career option in college women and men. Journal of Counseling Psychology, 28: 399-410.

[7] Betz, N.E., \& Hackket, G. (1999). Manual of the [25] occupational Self Efficacy Scale. Ohio State University \& Arizona State University.

[8] Betz, N. E., Klein, K. L., \& Taylor, K. M. (1996). Evaluation of a short form of the Career Decision Making Self-Efficacy Scale. Journal of Career Assessment, 4, 47-57.

[9] Brown, M. T. (2000). Blueprint for the assessment of socio-structural influences in career choice and decision making. Journal of Career Assessment, 8, 371-378.

[10] Bleir, J.K. (2006). The impact of career counseling plus discover (internet version) on

[11] The academic achievement of high school sophomores at risk for dropping out of school. The Faculty of the Graduate School Doctor of Philosophy. University of Missouri-Columbia.

[12] Campbell, D.T. \& Stanley, J.C. (1963). Experimental and quasi-experimental designs for research. Chicago, Illinois: Rand McNally. Programs. Alexandria, VA: American School Counselor Association Press.

[13] Castellano, M., Stone, J. R., Stringfield, S., Farley, E. N., \& Wayman, J. C. (2004). The effect of

[14] CT enhances whole-school reform on student course taking and performance in English and science. St.
Paul, MN: National Research Center for Career and Technical Education, University of Minnesota.

[15] Crites, J.O. (1978). Career maturity inventory: Theory and research handbook. California: CTB/Mc Graw Hill.

[16] M. Coetzee, H Roythorne-Jacobs. (2007). Career counseling and guidance in the workplace: A manual for career practitioners. Juta and Company ltd.

[17] Daria Williamson. (2006). The effect of career education mini- course on the career decision-making skills of high school students. Doc. Of Philosophy: University of Georgia.

[18] Devarajoo Ponnan. (2002). Kesan modul motivasi ke atas sikap kematangan kerjaya di kalangan pelajar sekolah menengah di Selangor. Tesis Sarjana Universiti Putra Malaysia.Serdang. Ettinger, J. 1998. Sharping tomorrowes workforce today. High school magazine,5,26-31.

[19] Gail Ann Kelly Roaten. (2004). The effents of a career development intervention on the career decision making skills of high school student. Doc. Of Philosophy: Texas A\&M University.

[20] Gysbers, N.C., Heppner, M.J. \& Johnston J.A. 2003. Career counselling process, issues, and techniques. Boston : Allyn and Bacon.

[21] Hasan Bozgeyikli., Susran E., Habib, 2009. Career Decision Making Self Efficacy, Career Maturity and Socioeconomic Status With Turkish Youth. Journal of Science and Psychology, 14:1-10.

[22] Hughes, K.L \& Karp,M.M. (2004). School-based careeer development: a synthesis of the literature. New York: IEE, teaching College,Columbia University.

[23] Jacob, N. Sneva. (2011) . Exploring career decisionmaking self-efficacy, career maturity

[24] Attitudes and racial identity attitudes of college students of color. Doc. Of Philosophy: State University of New York, U.S.

Jean Miles. (2008). The impact of a career development programme on career maturity and academic motivation. Doc. Of Philosophy: Fort Hare University, London.

[26] Kementerian Pengajian Tinggi Malaysia. (2008). Laporan pengesanan graduan. Bahagian Pengurusan Kolej Komuniti.

[27] Legum, H. L., Hoare, C. H. (2004). Impact of a Career Intervention on At- Risk Middle School Studentse Career Maturity Levels, Academic Achievement, and Self-Esteem.Professional School Counselling, Vol. 8, Issue 2.

[28] Lent, R.W., Brown, S.D. \& Hackket, G. (1994). Social kognitive approach to career development: An overview. The Career Development Quarterly,44: 311321.

[29] Medianta, T. (2011). Career Planning Program to Increase Career Search Self Efficacy in Fresh Graduates. Journal of Higher Education Theory and Practice. 11 (4). 75-87.

[30] Medina, Bertha .(2010). Career Course Impact on Adolescent's level of Career Decision Self Efficacy, Hope and Self Esteem. Prescott Valley Arizona.

[31] Mitchell, T.R., Hooper, H, Daniels, D. George -Falvy \& James, L.R. (2004). Predicting self-efficacy and

\section{Volume 5 Issue 4, April 2016}




\section{International Journal of Science and Research (IJSR) \\ ISSN (Online): 2319-7064}

Index Copernicus Value (2013): 6.14 | Impact Factor (2015): 6.391

performance during skill acquisition. Journal of Applied Psychology. 79: 506-517.

[32] Miles, J. (2008). The Impact of a Career Development Programed on Career Maturity and academic Motivation. Degree of Master of Sicial Scienes.

[33] Mizan Adiliah. (2005). Kajian Mobaliti Perkhidmatan Bimbingan dan Kaunseling Kolej Komuniti. Kementerian Pengajian Tinggi Malaysia.

[34] Poh Li, Lau, Aqeel, Khan , Haslee Sharil Abdullah and Fong Peng Chew. (2010). The

[35] Effectiveness of Career Exploration Program for High SchoolStudents. University of Malaya Faculty of Education, Kuala Lumpur

[36] Richard G. Brake,M.A. (2001). The effects of discover career guidancesoftware on career decision-makingself efficacy of adolescents in foster care. Doc. Of Philosophy. Our Lady of The Lake University, Texas.

[37] Sani, I. (2011). Career maturity, career self-efficacy and studentse involvement in career counseling and guidance activities. Unpublished Doctoral Dissertation, National University of Malaysia, Bangi.

[38] Sara, J. Munger, (2006). The impact of a career exploration group. Doc.Of Philosophy: State University of New York College.

[39] Scott, A.B., \& Ciani, K.D. (2008). Effect of an undergraduate career class on men's and women's career decision-making self-efficacy and vocational identity. Journal of Career Development.

[40] Schreuder, A.M.G., \& Coetzee, M. (2006). Careers: An organizational perspective. Cape Town: Juta \& Company.

[41] Syed Mohamad Syed Abdullah. (2005). Keberkesanan modul merancang kerjaya ke atas motivasi belajar, Kemahiran belajar dan kebolehan merancang kerjaya pelajar berpencapaian rendah. Tesis Dr. Falsafah. Universiti Kebangsaan Malaysia. Bangi.

[42] Super D.E. (1957). The Psychology of career. New York: Harper \& Row Publisher. Career Information, Career Counselling \& Career Development. $7^{\text {th }}$, Ed. Boston: Allyn and Bacon.

[43] Tan Wat Jin. (2004). Kesan pelaksanaan modul kerjaya terhadap kematangan kerjaya pelajar sekolah menengah. Tesis Sarjana . Universiti Putra Malaysia, Serdang.

[44] Thuria, M. (2003). The impact of career development classes on the identity development

[45] and career self efficacyof traditional aged college students. Dissertation of Doc. Of Philosophy: School of the Ohio State University.

\section{Author Profile}

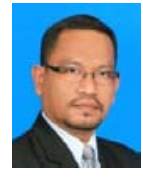

Mohd Jahidi bin Rosdi received the B.T. degrees in Electrical Engineering \& Education from University Technology of Malaysia (UTM) in 1997. During 1990-1994, he was teaching at vocational school at Seremban, Ministry of Education of Malaysia. He still working at Jempol Community College until now, also involving in setting up technical education in Acheh, Indonesia at 2009-2010.

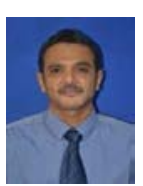

Jasmi bin Abu Talib received the Phd in guidance \& counseling from National University of Malaysia (UKM) in 2014. He also has masters" degree in guidance \& counseling at the same university at 2008, BS in guidance \& counseling at 2002 also at the same university. He also have a lot experience in teaching in secondary school at Melaka, start from 2014-2015 he was teaching at Masjid Tanah, community college. He is transfer to Terengganu University of Malaysia since Feb 2015 until know. 